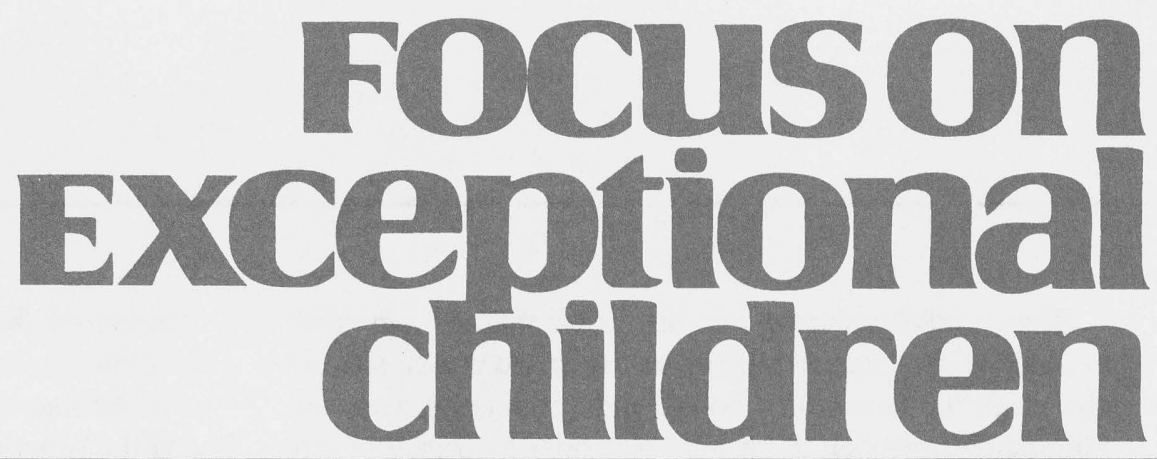

\title{
Effective Behavior Support: A Systems Approach to Proactive Schoolwide Management
}

\author{
Timothy J. Lewis and George Sugai
}

Being an educator in today's American schools demands more than teaching reading, math, science, arts, and other academic content. Today's educator must be able to accommodate students with significant learning and behavioral problems, teach in communities that are unable to support the school, and to work under conditions that are often counterproductive to teaching and learning. The impact of these conditions is felt in schools, neighborhoods, and families in a variety of ways.

- Problem behavior is the single most common reason why students with disabilities are removed from regular school, work, and home settings (Reichle, 1990).

- Up to $25.6 \%$ of eighth grade students reported they have been involved in a physical conflict with peers (U.S. Department of Education, 1995).

- Only half of American school children report feeling safe in their schools (Leitman \& Binns, 1993).

- One third of parents nationally do not think their children are safe at school or in their neighborhood (Rose \& Gallup, 1998).

- Three years after leaving school, 70\% of antisocial youth have been arrested (Walker, Colvin, \& Ramsey, 1995).

- $82 \%$ of crimes are committed by people who have dropped out of school (APA Commission on Youth Violence, 1993).

- More than half of all crime in the United States is committed by 5\%-7\% of youth between 10 and 20 years of age. (APA Commission on Youth Violence, 1993).

- Almost 16\% of high school students report being threatened with a weapon (U.S. Department of Education, 1995).

- Eighth grade students report that up to $16.9 \%$ of their peers bring weapons to school (U.S. Department of Education, 1995).

- "If antisocial behavior is not changed by the end of grade 3 , it should be treated as a chronic condition much like diabetes. That is, it cannot be cured, but managed with the appropriate supports and continuing intervention" (Walker, Colvin, \& Ramsey, 1995, p. 6).

Dr. Lewis is an Associate Professor in the Department of Special Education, University of Missouri. Dr. Sugai is a Professor in the Department of Special Education and Community Resources and Co-Director of the Center on Positive Behavioral Intervention and Supports, University of Oregon.

The Center on Positive Behavioral Intervention and Supports is supported by a grant from the Office of Special Education Programs, with additional funding from the Safe and Drug Free Schools Program, U.S. Department of Education (H326S980003). Opinions expressed herein are those of the authors and do not necessarily reflect the position of the U.S. Department of Education, and such endorsements should not be inferred. 
These facts emphasize that preparing children and youth to succeed in a dramatically changing world is a significant challenge for families, schools, and community agencies. Fortunately, many children and youth adjust reasonably well to these changes and challenges. These children and youth acquire the necessary skills to function in society through support from school, family, peer, work, and community experiences. Success is associated with having appropriate models available, having their actions monitored regularly, having regular opportunities for academic and social success, and having access to meaningful feedback that guides their behavior (Sugai \& Lewis, 1996).

Unfortunately, not all children and youth have access to appropriate models, regular monitoring, regular academic and social success, and meaningful feedback. Instead, for some children, social experiences are best characterized as reactive, aversive, infrequent, haphazard, and trial-and-error learning experiences. In fact, children and youth who are atrisk of or display antisocial behavior are an ever-increasing concern in American schools and communities. Extreme forms of problem behavior, such as aggression and violence, have reached epidemic proportions (Koop \& Lundberg, 1992;

\section{Focuson
Exceptional
children}

ISSN 0015-511X FOCUS ON EXCEPTIONAL CHILDREN (USPS 203-360) is published monthly except June, July, and August as a service to teachers, special educators, curriculum specialists, administrators, and those concerned with the special education of exceptional children. This publication is annotated and indexed by the ERIC Clearinghouse on Handicapped and Gifted children for publication in the monthly Current Index to Journals in Education (CIJE) and the quarterly index, Exceptional Children Education Resources (ECER). The full text of Focus on Exceptional Children is also available in the electronic versions of the Education Index. It is also available in microfilm from Xerox University Microfilms, Ann Arbor, MI. Subscription rates: Individual, $\$ 30$ per year; institutions, \$40 per year. Copyright (c) 1999, Love Publishing Company. All rights reserved. Reproduction in whole or part without written permission is prohibited. Printed in the United States of America. Periodicals postage is paid at Denver, Colorado. POSTMASTER: Send address changes to:

$$
\begin{gathered}
\text { Love Publishing Company } \\
\text { Executive and Editorial Office } \\
\text { P.O. Box } 22353 \\
\text { Denver, Colorado } 80222 \\
\text { Telephone (303) 221-7333 }
\end{gathered}
$$

Edward L. Meyen

University of Kansas Georgia State University
Glenn A. Vergason

Richard J. Whelan

University of Kansas Medical Center
Rutherford \& Nelson, 1995). As a result, school discipline continues to be one of the top concerns of American educators (Elements of an effective discipline strategy, 1995-96) and the American public (Elam, Rose, \& Gallup, 1998).

To understand why children and youth engage in challenging behavior, researchers have established compelling evidence that parents and communities contribute to the development of the most severe forms of antisocial behavior by failing to provide necessary prerequisite social skills and support and by modeling inappropriate social interactions. For example, researchers at the Oregon Social Learning Center have documented a strong link between inconsistent and harsh behavior management practices at home and later school- and community-related antisocial behavior by children and youth (Dishion \& Andrews, 1995; Dishion, Patterson, Stoolmiller, \& Skinner, 1991; Patterson, Reid, \& Dishion, 1992). In addition, Biglan (1993, 1995) has described the lack of prosocial engagement in the community and the resulting network of antisocial peers as clear correlates of further problematic and more deviant behavior.

Given that children may come to school with learning histories that set them up for further behavioral problems, schools must respond proactively and consistently. Unfortunately, evidence also suggests that current school discipline practices exacerbate and contribute to children and youth's patterns of challenging behavior. For example, Mayer and his colleagues have documented several school correlates commonly associated with school discipline practices that contribute to increasing rates of problem behavior (Mayer, 1995; Mayer \& Butterworth, 1979, 1981; Mayer, Nafpaktitis, Butterworth, \& Hollingsworth, 1987).

High rates of antisocial behavior in school are associated with punitive disciplinary strategies, lack of clarity about rules, expectations, and consequences, lack of staff support, and failure to consider and accommodate individual differences (Mayer, 1995). In addition, recent reviews of the literature report that the least effective responses to violence in schools are counseling, psychotherapy, and punishment-all common school responses (Gottfredson \& Gottfredson, 1996; Lipsey, 1991, 1992; Lipsey \& Wilson, 1993; Tolan \& Guerra, 1994). Furthermore, Mayer and Sulzer-Azeroff (1991) found that punishing problem behaviors without a positive schoolwide system of support was associated with increased aggression, vandalism, truancy, tardiness, and dropouts. Yet, the call to "get tougher" on problem behaviors by increasing punishments continues to permeate the educational literature (e.g., Elements of an effective discipline strategy, 1995-96).

In their comprehensive review of the literature on reducing juvenile crime, Ziglar, Taussig, and Black (1992) concluded that early intervention/prevention programs are perhaps the best hope we have for reducing serious behavior challenges, 
particularly as children enter adolescence. Likewise, in their review of interventions designed to remediate violent and antisocial behavior, Tolan and Guerra (1994) concluded that once a pattern of antisocial behavior has been established, no intervention strategy was effective in significantly reducing violent behavior among adolescents. As the literature indicates, early patterns of challenging behavior, coupled with limited or inappropriate parent supervision, set up children and youth for school failure, dropping out of school, and incarceration.

Equally disturbing is the low success rate of current programs designed to serve children and youth with emotional and behavior disorders (EBD). Of students labeled EBD, $50 \%$ drop out of school, the highest rate of all disability categories (U.S. Department of Education, 1994). Of those who remain in school, only $42 \%$ graduate with a diploma (Wagner, 1991). Additional information collected by Wagner and reported by the U. S. Department of Education (1994) suggest that students with EBD present increasing, significant, and exceptional challenges to the public schools and community, for example:

(a) "students with EBD have lower grades than any other group of students with disabilities" (p. 109)

(b) "data also suggest that there is a high disproportion of students from disadvantaged socioeconomic backgrounds and a low disproportion of female students among those identified with EBD" (p. 110)

(c) " $20 \%$ of students with EBD are arrested at least once before they leave school, and 35\% are arrested within a few years of leaving school" (p. 110).

Overall, students with EBD face bleak post-school outcomes, including unemployment and poor social support. The present level of services for students with EBD is best summarized by Walker and Bullis (1990):

\footnotetext{
The public schools' record of effectively accommodating students with behavioral disorders...is close to abysmal...[A] strong case can be made regarding their neglect of students experiencing serious behavior problems. (p. 78)
}

\section{EFFECTIVE BEHAVIORAL SUPPORT RESPONSE}

On a positive note, recent reviews of the literature indicate that schools and parents can be successful in reducing challenging behavior by implementing a proactive prevention and early intervention program (Conduct Problems Prevention Research Group, 1992; Dodge \& The Conduct Problems Prevention Research Group, 1993; Elliot, 1994a, 1994b; Gottfredson \& Gottfredson, 1996; Larson, 1994; Sugai \& Horner, 1994; Tolan \& Guerra, 1994; Walker et al.,
1995, 1996; Ziglar et al., 1992). Recommended strategies include the following, among others:

1. Parent training. Teaching parents to increase positive interactions, increase active supervision of their children, and actively participate in their child's education (Conduct Problem Prevention Research Group, 1992; Elliot, 1994a, 1994b; Larson, 1994; Patterson, Reid, \& Dishion, 1992; Tolan \& Guerra, 1994; Walker, Colvin, \& Ramsey, 1995; Webster-Stratton \& Spitzer, 1996).

2. Social skill training. Direct and planned instruction designed to teach specific social behavior that, when displayed by the student, results in positive judgments of social competence from peers and adults (Gresham, 1998; Lipsey, 1991; Lewis, 1996; Lewis, Chard, \& Scott, 1994; Mayer, 1995; Peacock Hill Working Group, 1991; Sugai \& Horner, 1994; Sugai \& Lewis, 1996; Walker et al., 1996).

3. Academic and curricular restructuring. Creating and adapting curriculum to ensure that children are successful learners, self-esteem is bolstered, and problem behavior is reduced (Colvin, Kameenui, \& Sugai, 1993; Lipsey, 1991; Kameenui \& Simmons, 1990; Tolan \& Guerra, 1994; Walker et al., 1996).

4. Proactive management. Schools and ather educational agencies engage in preventive management (e.g., teach school expectations, provide practice opportunities) strategies before problem behaviors escalate (Colvin et al., 1993; Cotton, 1995; Cotton \& Wikelund, 1990; Lewis et al., 1994; Lipsey, 1991; Noguera, 1995; Sugai \& Horner, 1994; Walker et al., 1996).

5. Individual behavioral interventions. Individual interventions emphasize the use of functional assessment and instructional interventions (Dunlap et al., 1993; Lalli, Browder, Mace, \& Brown, 1993; Lewis \& Sugai, 1996a; Lipsey, 1991; Walker et al., 1995, 1996).

The technology to change behavior and impact children's lives is readily available within the professional literature (Sugai, 1998; Sugai \& Horner, 1994, in press; Walker et al., 1996). Nevertheless, the critical step in translating empirically validated research into best practice is a systemic change in how schools approach problem behavior. The purpose of this article is to describe essential features of a schoolwide proactive management system termed "Effective Behavioral Support" (Lewis, Sugai, \& Colvin, 1998; Lewis, Colvin, \& Sugai, in press; Lewis, 1996; Sugai \& Horner, 1994, in press). We present a definition and an overview of the features of EBS, descriptions of levels of EBS, and a case example. 


\section{WHAT IS EFFECTIVE BEHAVIORAL SUPPORT?}

Effective Behavioral Support (EBS) is a systems approach to enhancing the capacity of schools to adopt and sustain the use of effective practices for all students. EBS is a teambased process for systemic problem solving and planning; it is not a model or curriculum. In the EBS approach, schoolbased teams of educators are provided with training in (a) systems change and management principles and practices, and (b) applications of research-validated instructional and management practices at the schoolwide, classroom, nonclassroom, and individual student levels. Established teams (a) secure commitments to the process from administrators and classified and certified staff, (b) review the status of behavior support and disciplinary practices in their schools, and (c) develop or adapt implementation action plans to address their building's unique student and staff needs. The ultimate goal of EBS is to increase the school's capacity to address effectively and efficiently the behavioral support needs of all students and staff.

Another important EBS feature is attention to increasing ongoing and meaningful staff development opportunities. Guskey (1986) noted that: (a) "nearly every major work on the topic of staff development has emphasized the failings of these efforts " (p. 5), and (b) the majority of staff development fails to consider two factors: "what motivates teachers to engage in staff development, and the process by which change in teachers typically takes place" (p. 6).

Guskey concluded that any successful professional development endeavor should attend to three critical variables:

\footnotetext{
First, change is a slow, difficult, gradual process for teachers; second, teachers need to receive regular feedback on student learning outcomes; and third, continued support and follow-up are necessary after initial training. (pp. 9-10)
}

The EBS approach incorporates all three of Guskey's recommendations by addressing the factors that "motivate" teachers to change and using a proven "process" for change. For example, an important prerequisite for successful systemic change is for schools to formalize the process by (a) making the EBS effort one of their top three school improvement priorities or initiatives, (b) collecting and reporting school performance data (e.g., office discipline referrals, behavior incidents reports, attendance/truancy rates) on an ongoing basis, and (c) arranging for onsite technical assistance.

Using the principles of effective instruction, incorporating empirically validated behavior-change techniques, focusing on a systems approach, and attending to effective strategies for professional development, the EBS approach is designed to meet the unique needs of each school through three broad levels of implementation (see Figure 1) (Colvin et al., 1994; Sugai \& Horner, in press; Taylor-Greene et al., 1997).
First, school teams develop primary or universal schoolwide management strategies designed to meet the needs of all students and develop a common language and focus for school staff, families, and community members. Universal management strategies are designed to be implemented consistently and efficiently across all school settings, staff, and students. In addition, special adaptations and extensions of the schoolwide system are developed to address the unique needs of specific nonclassroom (e.g., cafeteria, hallways, bus, playground) and classroom settings.

Second, secondary support interventions are developed to provide targeted or specialized group-based strategies for individuals who present significant risk factors (e.g., low academic achievement, poor peer affiliations, limited family/community supports) and who require repeated practice and environmental modifications to increase their likelihood of academic and social success.

Third, tertiary systems of support are developed to provide targeted and highly specialized strategies for the relatively small number (approximately 1\%-7\%) of students who engage in chronic challenging behavior that is unresponsive to universal and group based interventions.

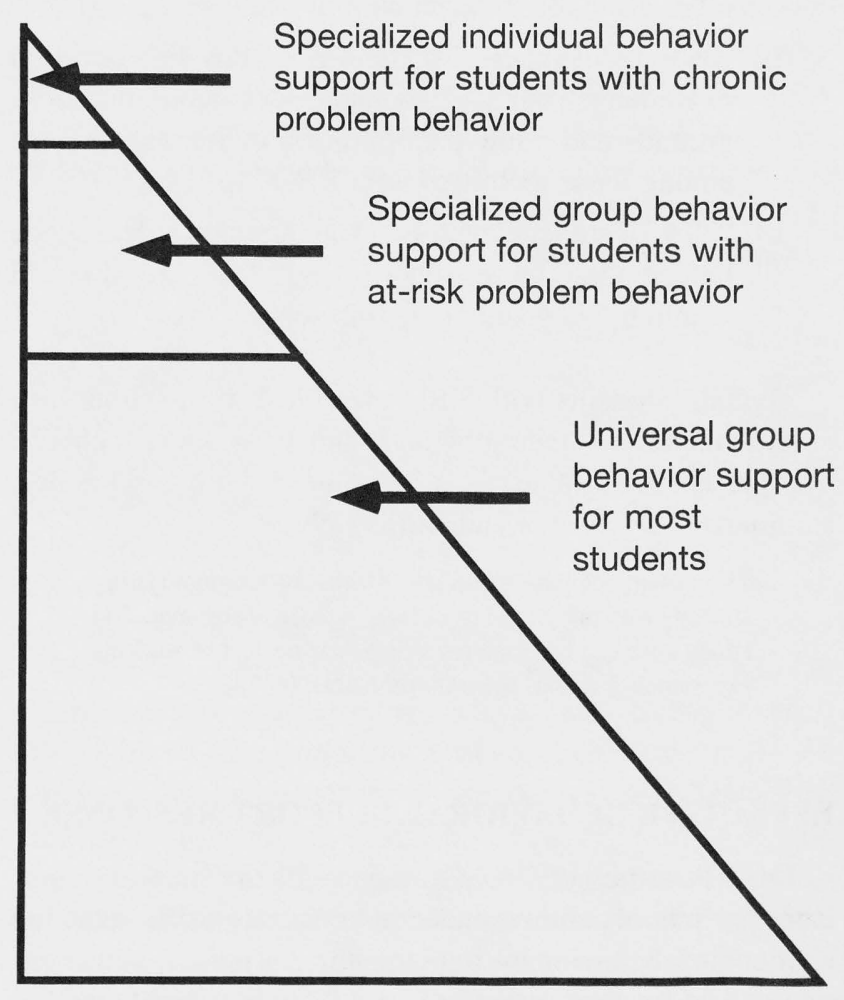

Total Student Enrollment

FIGURE 1

Continuum of positive behavioral support. 
In the following section, the application of these three levels of implementation are represented across four major school systems: (a) schoolwide, (b) nonclassroom, (c) classroom, and (d) individual student. The generic steps for implementation of the EBS approach and case study examples are highlighted.

\section{SCHOOLWIDE EBS}

The EBS approach is founded on establishment of a proactive schoolwide system of behavior support. This first level of implementation has a common approach to discipline that emphasizes teaching all students key behavioral expectations and routines and establishing a proactive means of communication for students and staff. Students are taught specifically what they should and should not do to be successful in school. In addition, this positive, preventionbased emphasis teaches behavioral expectations within real school settings or contexts where the behaviors are required.

\section{Preparation for Implementation}

The first step in implementing EBS is to form a team composed of representative school staff (e.g., grade level, specialists, support, and paraprofessional personnel). Including an administrator is considered essential to the team's successful and efficient functioning. Once established, the team should develop a regular schedule for its meetings. A prescribed day and time preserves the efforts and momentum of the team, protects the team from conflicts with other school activities, and keeps the work of the EBS team a high priority. In larger schools, a standard system for communicating information from the committee to all staff should be established, such as a regular EBS item on the faculty meeting agenda, quarterly newsletter, Web-based announcements, or memos.

The next step entails conducting a needs assessment to establish what currently is being implemented, what remains to be completed, and what is deemed high priority (see the Appendix for a sample needs assessment survey). Once the needs assessment and analysis are complete, the team establishes an action plan that specifies activities to be accomplished, and specifics about how, when, by whom, and where. In addition, the team targets staff development needs. Opportunities to provide and receive training in key areas are outlined, and strategies are developed for sharing information with parents and key community members (e.g., mental health, juvenile justice, family services).

\section{Necessary Elements of a Schoolwide Behavior Support System}

The schoolwide EBS effort has six essential elements: (a) statement of purpose, (b) schoolwide expectations, (c) procedure for teaching schoolwide expectations, (d) continuum of procedures for encouraging schoolwide expectations, (e) continuum of procedures for discouraging problem behaviors, and (f) procedures for monitoring the impact of the school-wide EBS implementation.

\section{Statement of purpose}

Every school should have a statement that describes its purpose and approach to teaching and learning, and that serves as the foundation or mission statement for its activities, decisions, and way of doing business. This statement should be positive and brief; encompass all student, staff, and settings; and consider academic and behavioral outcomes. The following is an example of a statement of purpose that could be used across grade levels:

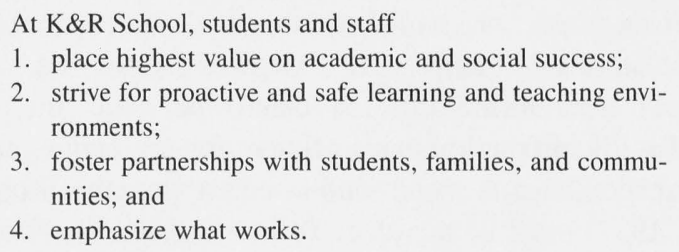

\section{Schoolwide behavioral rules or expectations}

Building on the statement of purpose, every school should have a clearly stated list of expected behaviors based on the commonly occurring problem behaviors observed across school settings. For each problem behavior, schools should identify a "replacement" behavior, or statement about "what do you want the student to do instead?" Replacement behaviors should be stated in positive, observable terms and focus on behaviors that are age-appropriate.

Once the list of replacement behaviors is generated, behaviors should be grouped to form a set of three to five succinct schoolwide rules or expectations that will serve as a common means of communications across the school. For example, Durham Elementary School in the Portland, Oregon area organized its schoolwide EBS effort around Project Respect and developed three school rules: Respect yourself, respect others, and respect property. Willard Elementary School in Eugene, Oregon generated five rules: Be respectful, be cooperative, be safe, be kind, and be peaceful.

For each schoolwide expectation or rule, two levels of replacement behaviors should be generated. First, a set of generic behavioral exemplars for each rule should be developed that can be applied across most school settings. For example, "be kind" might be defined as including others, using polite words, keeping hands to self, helping others, being a friend.

\section{Procedures for Teaching Expected Behavior}

Once a set of rules and specific replacement behaviors are developed, the next step is to teach the behaviors to all students. Because schools have a variety of ways available 
to them to teach targeted social skills, they must make curriculum and instructional decisions based on the unique features of their students, staff, and school. At a minimum, schools must follow research-validated practices to maximize the likelihood of successful acquisition of social skills. In particular, schools should institute practices that "tell" the students what is expected, "show" them what the skill looks like, and "practice" the skills through role plays and in-vivo situations (Gresham, 1998; Sugai \& Lewis, 1996).

For example, social-skill instructional strategies could include scripted lessons using direct instruction (see Lewis et al., 1998), videotaped exemplars using students, generating lists of suggested teaching activities, and creating resource libraries with instructional strategies and related resources, such as published social skills curricula and related stories that emphasize a targeted school rule.

The research literature is clear that acquisition-level social skills instruction is insufficient for achieving generalized responding. A "train-and-hope" approach (Stokes \& Baer, 1977) must be avoided. To increase the likelihood of students using social skills appropriately across people, places, and situations, teaching procedures should include multiple examples, practice within and across multiple settings, instruction on self-management skills, and involvement of a variety of people.

\section{Procedures for Encouraging Expected Behavior}

Teaching an expectation is necessary but not sufficient for success in learning social skills. Schools also must provide incentives to encourage students to use prosocial skills (Alberto \& Troutman, 1998; Lewis et al., 1998; Wolery, Bailey, \& Sugai, 1988). Most school teams have operationalized this component into some form of a paper token or coupon (e.g., "Gotcha" coupons, "Chance" tickets, "High Fives"). For example, Parkade Elementary in Columbia, Missouri, developed "Pride tickets" to support the larger school mission of increasing school pride. All teachers are given a stack of pride tickets for distribution to any student whom they observe complying with a schoolwide expectation. When a student earns a ticket, half of it is placed in a container located in each classroom. The student keeps the other half and takes it home. At monthly school assemblies, students are given updates on improvements in their behavior, and a drawing is held. When an individual student's pride ticket is drawn, he or she receives a school-related item (e.g., notebook, marker, book).

The critical element of any incentive system is not the token, or tangible, but, rather, the social acknowledgement and interaction between the student and the school. When teachers provide a token, they are instructed also to state what specific social skill the reward is for ("I noticed that you were using your words to solve that conflict"), state what larger school rule the student was following ("You were respecting others by managing the situation in a peaceful manner"), and provide a positive social acknowledgement ("I'm proud of your responsible behavior . . . excellent"). The emphasis once again is placed on the instructional sequence of pairing student behavior with predictable social outcomes (e.g., adult approval, access to privileges) and building proactive social relationships.

In any incentive system, plans also should be developed to fade the use of coupons while verbal feedback and other natural outcomes remain. A continuum of strategies for encouraging expected behaviors should be developed to reduce the use of external school incentives. More studentbased reinforcement maintains the desired behavior. In general, positive reinforcement should be shifted from (a) tangible to social, (b) external to internal, (c) frequent to infrequent, and (d) predictable to unpredictable (Sugai \& Tindal, 1993).

\section{Procedures for Discouraging Problem Behavior}

Even in the most proactive and consistent implementation of schoolwide procedures, some students are likely to make social behavioral learning errors (i.e., misbehave and violate schoolwide rules). Schools should review their existing codes of conduct and consequences for problem behavior. Given that most schools have some form of "discipline" policy in place to address major violations of rules (e.g., fighting, drugs, weapons), the critical task for schools is to develop a continuum of procedures for discouraging problem behavior.

Schools should develop (a) clearly defined examples of each rule-violating behavior and (b) specific decision rules for determining which consequence should be assigned to which problem behavior event. The goal is to develop a policy that (a) is implemented consistently schoolwide, (b) clearly differentiates what behaviors should be managed in the classroom and what behaviors should be sent to the office, and (c) provides a proactive strategy to identify and address the needs of students who have chronic problem behavior.

For example, at $\mathrm{K} \& \mathrm{R}$ School, three levels of ruleviolating behavior are specified: Level I includes minor problem behavior that typically is handled by classified and certified staff, unless a behavior becomes chronic (e.g., talkouts, tardies, unprepared); Level II encompasses major problem behavior that requires the involvement of an administrator (e.g., fighting, defiance/insubordination) and is associated with an office referral and consequence (e.g., suspension, detention); and Level III consists of illegal acts (e.g., vandalism, weapons) that requires district (e.g., board-sanctioned expulsion) or community involvement (e.g., juvenile justice). 


\section{Procedure for Record-keeping and Decision Making}

Essential to the success of any individual or systemwide behavior support plan is the use of data to make instructional decisions. Most schools collect information that can be used to assess the effectiveness of schoolwide procedures-for example, minor behavior reports; office discipline referrals; and records of attendance, truancy, and tardiness. Efforts by Colvin, Sugai, and Patching, (1993), Lewis-Palmer, Sugai, \& Larson (in press), Skiba, Peterson, \& Williams, (1997), Taylor-Greene et al. (1996), Tobin and Sugai (in press-a, b), and Tobin, Sugai, and Colvin (1996) indicate that office referral records can be a useful indicator of school climate and the functioning of schoolwide discipline systems, especially in middle and secondary schools.

EBS schools in Eugene and Tigard-Tualatin school districts in Oregon generate quarterly reports of office referral patterns to guide planning and decision making. In general, five main graphic displays are used: (a) number of office referrals per day in a given month (e.g., 3.5 referrals per day in the month of November), (b) cumulative number of office referrals by type of rule violation (e.g., repeated minors, defiance/insubordination, tardies, fighting), (c) cumulative number of office referrals by location (e.g., classroom, cafeteria, bus), (d) cumulative number of office referrals by consequence, and (e) cumulative number of office referrals by individual student (i.e., repeat offenders).

Regular analyses of office referrals over time can reveal patterns that guide schools in modifying their schoolwide systems. For example, at an elementary school in Tigard, Oregon, an analysis of office referrals indicated that more than $80 \%$ of office referrals were for fights that occurred during morning or afternoon recess. In addition, most of these referrals were assigned to about $8 \%$ of the student population (i.e., repeat offenders). The school used this information to institute a recess conflict management program and to increase the amount of attention given to students who were following playground and schoolwide rules.

\section{NONCLASSROOM SETTINGS}

Nonclassroom-setting interventions are extensions of larger schoolwide behavior support systems. The major difference is that procedures must be modified to accommodate the unique features of specific settings, such as cafeteria, bus, and hallways. These modifications focus on planning and developing setting-specific lesson plans, instructional strategies, and support structures. Figure 2 illustrates an extension of Willard Elementary's schoolwide set of expectations across specific school settings with setting specific behaviors.

\section{Preparation for Implementation}

The major prerequisite for implementation of nonclassroom setting systems is the sustained and effective use of a proactive schoolwide behavior support system. The previously described six elements of a schoolwide system serve as the foundation for all nonclassroom assessment, planning, and implementation efforts. Because nonclassroom settings tend to involve larger numbers of students than classroom contexts and focus on supervision instead of academic instruction, attention is directed toward (a) features of the physical environment, (b) establishing predictable routines, (c) teaching students appropriate setting-specific behaviors, and (d) focusing staff on the effective use of active supervision strategies.

\section{Implementation Activities}

Implementation of nonclassroom systems focuses on six major activities: (a) assessment of current and needed setting routines, (b) assessment of physical factors within the setting, (c) identification of setting-specific behaviors, (d) development of instructional strategies, (e) identification of needed support to implement the plan, and (f) implementation and monitoring.

\section{Assessment of routines}

The first implementation activity involves an assessment of current nonclassroom setting routines. Nelson and Colvin (1995) outlined a three-step process to evaluate and improve current and needed routines.

1. Identify existing and needed routines. Most schools have clearly articulated routines for some events (e.g., fire, bomb threat, earthquake) but fail to plan adequately for high-frequency routines, such as hallway transitions, entering and exiting common areas, and use of the restrooms.

2. Identify key student and staff behaviors that are required to complete routines successfully with minimal chance of problem behavior occurring.

3. Identify and develop strategies to teach, practice, and maintain the new routines.

\section{Assessment of Physical Characteristics of Nonclassroom Settings}

The second planning activity focuses on analysis of the physical characteristics of the nonclassroom setting. Attention should be focused on the (a) identification of unsafe objects that can be removed or made off-limits, (b) reduction of physical space that is difficult for staff to supervise, (c) provision of adequate space or efficient schedules during times in which long waits are required, such as cafeteria or bus lines, and (d) reduction of student density where possible in common areas (Nelson \& Colvin, 1995). The focus is on removing or modifying problematic features when possible 


\section{PLAYGROUND}

Be kind:

Invite others to join

Include all who want to play

Accept skill differences/teach rules to others

Include others in your activities

Be safe:

Use equipment appropriately

Stay in designated areas

Be cooperative:

Agree on game rules before you start to play

Follow game rules

Take turns

Use peer conflict meaditors to resolve conflicts

Be respectful:

Keep game rules the same during the game

Use appropriate language (no put-downs)

Line up when whistle blows

Be peaceful:

Problem-solve conflicts

Return from the playground quietly

\section{HALLWAY}

Be kind:

Keep hands and feet to self

Allow others to work when you enter the classroom

Be safe:

Walk

Watch where you are walking

Be cooperative:

Wait for directions before leaving

Follow rules without adult reminders

Get materials out, and be prepared to work as soon as you enter the classroom

Be respectful:

Walk quietly so other students can continue learning

Use polite language

Follow adult directions

Be peaceful:

Walk quietly

Enter classrooms quietly

\section{ASSEMBLIES}

Be kind:

Let people talk, listen to the presenter

Clap when finished

Be safe:

Enter and exit gym in an orderly manner

Be cooperative:

Take turns asking questions/answering questions

Be respectful:

Keep hands and feet to self

Be peaceful:

Enter and exit gym using quiet voices

\section{CAFETERIA}

Be kind:

Wait in line in order

Use polite words

Allow everyone to sit

Be safe:

Walk

Keep hands and feet to self in line

Watch out for others

Open the doors slowly

Keep food on your tray

Be cooperative:

Follow adult directions

Sit at assigned table

Wait to be dismissed

Put ticket in basket

Be respectful:

Follow adult directions (the first time)

Eat only your own food

Clean up after yourself

Be peaceful:

Use calm voices

Eat slowly

FIGURE 2

Willard schoolwide behavior program school rules and specific example behaviors.

or modifying routines and increasing supervision to lessen the likelihood of problem behavior occurring.

\section{Identification of Behavioral Examples}

The third activity involves identifying setting-specific behavioral examples that reflect each of the larger schoolwide rules. Behaviors should focus on what students should do, stated in positive, observable terms. Examples of inappropriate behaviors should be used during instruction to illus- trate what not to do. Instructional attention should be directed to desired behaviors and the conditions under which those behaviors are expected. Student input should be included when appropriate.

\section{Development of Teaching Strategies}

Once specific behaviors are identified, the next step is to develop strategies to teach setting-specific behaviors. Ideally, behavioral expectations should be taught uniformly through 
a common set of scripted social skill lessons (Lewis et al., 1998; Sugai \& Lewis, 1996). Social skills should be taught using clarifications of the critical rule (i.e., when to use the skill), demonstrations by the teacher, role-plays with the students, and social skill reviews (see Sugai \& Lewis, 1996 for a complete description of social skill best practices).

In addition, after setting-specific skills have been taught directly, teachers should review previously taught skills regularly and frequently. Social skills and rules also should be integrated across the curricula where appropriate. For example, students can be asked to write stories using school rules during language arts activities or to create posters illustrating school rules for each setting during art class.

Teachers can develop classroom plans that utilize peers to provide positive reinforcement to one another's use of expected behavior. For example, when a student demonstrates social skills in a nonclassroom setting, a classmate could place the student's name on the chalkboard in the classroom. Having classmates note the demonstration of an appropriate social skill not only provides positive reinforcement for the student who is demonstrating the skill but also may prompt other students to demonstrate the skill. Plans also should be made to provide sufficient practice of skills and strategies to promote use of social skills within and across each targeted setting.

\section{Identification and Securing of Support Requisites}

The final planning activity involves identifying and securing necessary support structures and resources to implement the plan effectively. For example, teachers need time to complete the previous activities (e.g., identification of pivotal behaviors, development of social skill lessons). Inservices may be required to train the staff on new routines and teaching strategies. Rearrangement of physical aspects of the school environment require approvals, accessing the appropriate personnel, securing materials, and the like. Staff schedules may have to be modified to provide for adequate supervision.

Finally, specific strategies may be required to promote the use of new skills and routines directly within a specific setting (Colvin, Sugai, Good, \& Lee, 1997; Lewis et al., in press). For example, precorrections (e.g., prompts or reminders of key behaviors required in problem situations) can be used to facilitate student transitions into new settings, faculty and staff may have to increase their level of active supervision (e.g., scanning, providing praise, providing error correction), and incentives may be required to encourage students to use new routines and skills.

\section{Implementation and Monitoring}

Once all planning activities are completed, a structured schedule for implementation should be developed and followed. All staff members should focus on teaching routines and related skills within a single setting. In addition, many opportunities should be provided for students to practice routines and skills and to receive feedback on their use of these skills and routines. For example, if the target setting is school assemblies, the staff would review routines for leaving the classroom, arriving at the auditorium, and following seating arrangements. Related social skills also should be taught, such as listening to the speaker, ignoring off-task peers, and asking appropriate questions.

Finally, the staff should hold assemblies to practice new routines and skills. Award assemblies related to improved school behavior provide opportunities both to practice new skills and to recognize and reward appropriate assemblyrelated behavior. Once new routines and skills are taught and opportunities to practice are provided, the staff can target other settings that might require attention.

An essential component of implementation is a system to monitor how effectively the activity has been implemented. Ideally, direct observation of the frequency of student problem behavior and replacement behavior should be conducted. If time or resources do not allow the staff to collect direct observation data, other strategies should be used. These might be anecdotal reports from the supervisory staff, rate of office referrals related to target settings, or random counts on a small group of students within the target setting. If the data indicate that the plan is not working, features of the plan and its implementation should be reviewed. Additional instruction, supervision, incentives, or practice with feedback may be needed to improve performance, or strategies for improving staff implementation (e.g., feedback incentives, training) may be required. If the data indicate the plan is working, specific strategies should be considered to ensure positive implementation over time (e.g., regular progress reviews, positive reinforcement, and acknowledgements for staff participation).

Figure 3 provides a summary of activities developed by Parkade Elementary School. Activities are listed following the above outlined steps.

\section{CLASSROOM SYSTEMS}

Classroom management systems tend to reflect individual teacher preferences and approaches, curriculum, and subject area (e.g., physics, reading, music, physical education) and level of teacher autonomy. When establishing classroom systems, the goal is not to create uniform classrooms. The intent is to extend the school-wide system so students can be successful given variations in instructional style and classroom routines. In addition, classroom management systems should overlap with schoolwide behavior support systems to facilitate communications among students, staff, and parents; increase the consistency with 


\section{Assessment and establishment of routines}

- Wait lines pre/post recess established

- Painted game area boundaries and "wait spots"

- Marked starting point for playground equipment

\section{Assessment and limitation of physical characteristics}

- Created specific boundaries-designated off-limit areas

\section{Identification of behavioral examples}

- Teachers observed for social skill problems

- Students observed other grade levels for problem spots

- P.E. teacher, with student input, identified key rules of popular games

\section{Development of teaching strategies}

- Staff developed scripted social skill lessons

- All staff taught social skills in classroom

- All staff taught social skills on the playground

- P.E. teacher reviewed/taught safe use of all equipment

- P.E. teacher reviewed rules of popular games

- Classroom teachers and playground monitors reviewed rules of games

\section{Support structures}

- Pre-correct system for staff and students

- Incentive system

- Posted rules for games near equipment

\section{Monitoring}

- Data collection system (class lists) to record offenses and compliance

\section{FIGURE 3}

Parkade EBS playground plan.

which behavior is handled by staff in classroom, nonclassroom, and office situations; and ease transitions when students move within and across different school settings. The ultimate goal is to increase predictability for students, staff, and visitors.

\section{Preparation for Implementation}

Unlike the implementation of schoolwide and nonclassroom systems that are guided by a schoolwide team and involve all staff members in a uniform plan of action, implementation of classroom management systems are led by individual classroom teachers. Although staff development activities on improving classrooms might be conducted schoolwide, implementation is the responsibility of the classroom teacher. To illustrate how classroom management systems are individualized and how schoolwide systems are extended into classrooms, teachers are encouraged to answer the following questions proposed by Kameenui and Simmons (1990, pp. 476-477):

- What do I want my classroom to look like?

- How do I want children to treat me as a person?

- How do I want children to treat one another?

- What kind of information or values do I want to communicate to students about being an adult, an educator, a woman or a man in today's society?

- How do I want children to remember me when the last day of school ends and I am no longer part of their daily lives?

In addition, to these questions, teachers should consider how their individual responses (a) relate to the larger school purpose and set of expectations and (b) enhance student success. For example, if a classroom has multiple centers focusing on student-directed learning, a set of classroom expectations should be created that is aligned with the schoolwide expectations, and, more important, an assessment should be conducted to ascertain if students have the requisite academic and social skills to learn in this type of classroom arrangement. Teachers should not assume that students have the requisite skills. It is better to err on the side of overteaching than not teaching at all.

\section{Implementation Activities}

Over the past 30 years, a clearly defined research-validated literature base exists on effective classroom management practices, and a variety of reviews and guides summarize this literature (Alberto \& Troutman, 1998; Charles, 1996; Colvin \& Lazar, 1997; Kameenui \& Darch, 1996; Kerr \& Nelson, 1998; Sugai \& Tindal, 1993). Based on this literature, a number of common classroom management recommendations should be considered, as outlined below.

\section{Provide advance organizers/precorrections}

After students have acquired key replacement behaviors, they also must use prosocial behaviors more consistently and often than problem behavior. One strategy to promote fluency is to provide salient and clear expectations for student behavior. Precorrections function as reminders by providing students with opportunities to practice or be prompted about expected behavior before they enter situations in 
which displays of expected behaviors are low-probability events (Colvin, Sugai, \& Patching, 1993). For example, a teacher states the following: "Remember, before you go to homeroom, collect all your materials, put your work on my desk, and quietly line up" or, "What are your responsibilities before you go to homeroom?" The teacher also can model or demonstrate examples and nonexamples of critical skills.

\section{Keep students engaged}

During teacher instruction, students go "off-task" because (a) the instructional activities do not maintain student attention, (b) insufficient positive reinforcement is being provided, or (c) students access positive reinforcement from other activities or individuals. The teacher's task is to make sure that all students are engaged at some level with the instruction and compete with peer attention.

A simple way to engage students is to ask frequent questions. Initially, questions should be nondirected-for example, asking questions to the larger group. Following a brief pause ( $2-3$ seconds), questions can be directed toward specific students, especially those who do not seem to be engaged with the instruction. Questions also can be directed toward the whole group when "choral" responses are possible (e.g., "What is the first school rule?"). Although individual responses may not be heard, those who do not respond can be engaged through other strategies.

An additional strategy to engage students during instruction is to assign specific tasks during the lesson. For example, a selected student can be asked to see if other students "raise hand first," or a student might watch to see if the teacher demonstrates the skill/example correctly, and so on. This strategy is useful in bringing in students who tend to disengage when others are answering questions or who may not be as skilled as their peers in responding to the lesson requirements.

One of the most difficult tasks teachers face is competing for student attention. Peers often value laughter and conversation more than "getting a grade," learning, or getting teacher recognition for their making correct responses. When students compete for teacher attention several strategies can be implemented.

- The whole class should be instructed and encouraged to "pay attention" and ignore off-task peers (e.g., "Don't laugh when peers make comments, and ignore students who call out"). A rationale should be provided for why teachers should ignore students who do not follow the rules. Teachers should emphasize expected behaviors through examples and nonexamples, practice, and role-plays. They should give positive reinforcement to students who ignore off-task behavior.
- When students are off-task with peers, direct questions to one of the peers to redirect students back to task. Similarly, peers sitting near off-task students can be heavily reinforced with verbal praise ("Thank you, Michael and Emilie, for paying attention and following directions") paired with tangible outcomes ("You may leave for recess two minutes early"). Physical proximity and nonverbal prompts, (e.g., pointing to the text) also can be used to reengage students.

- Arrange seating to isolate students who have a history of off-task behavior or to reduce the impact of their off-task behavior.

\section{Provide a positive focus}

Even though peer attention is a powerful motivator for students, teacher attention also can be a useful positive reinforcer. To promote desired student behavior, teachers should communicate high and positive expectations, have more positive than negative interactions, catch problem behavior before it escalates or becomes more severe, and provide a lot of positive reinforcement. By presenting a positive model, teachers can promote a more positive classroom climate in which students are more likely to follow rules.

A rule of thumb is to provide four or more positive reinforcers for each correction or reprimand for rule-violating behavior. Positive reinforcers can be overt, tangible events (e.g., stickers, tokens, minutes of computer time) or covert, social events (e.g., smiles, winks, handshake, joke).

Also, teachers should pay attention to the effect of their actions on future occurrences of student behavior. If problem behavior does not decrease when, for example, teachers write the student's name on the chalkboard, give corrective reprimands, or assign lunch detention or office referrals, the problem behavior probably is being reinforced (i.e., not punished). If an expected behavior is not increasing when teachers provide, for example, tokens or verbal praise, these events are not functioning as effective positive reinforcers. A reinforcer, again, is any action or event that follows a behavior and that is associated with increases in future rates of that behavior.

In general, the best strategy is to ignore as much inappropriate behavior as possible and, instead, attend to and praise peers who are not doing the behavior (e.g., "Thanks, Kiyoshi, for remembering to raise your hand before talking"). This strategy takes attention away from the student who is displaying problem behavior and provides an instructional model ("If you want my attention, follow the rule like [a peer]").

\section{Consistently enforce school/class rules}

If all students are expected to engage in appropriate behavior, rules and consequences should be the same for all 
students. For example, the teacher should call on and reinforce only the students who raise their hand during largegroup instruction. The way in which the student is called upon and positively reinforced, however, might vary. One student might find public acknowledgements positively reinforcing, and another might find the same event highly aversive. In addition, expectations, outcomes, and behavior can, and should, vary across setting (e.g., "You don't have to raise your hand to talk in small groups").

If teachers are consistent in their positive reinforcement of expected behavior and enforcement of classroom rules, students will recognize what behavior is expected based on critical classroom and teacher cues, signals, and prompts. For example, when in the classroom, students will learn to access adult attention by raising their hand. In contrast, when students are on the playground, they will learn to gain adult attention by using their words.

\section{Correct rule violations and social behavior errors proactively}

At times, ignoring problem behavior (e.g., peer-maintained problem behavior, highly disruptive behavior, verbally or physically threatening events, high-frequency/intensity behaviors) is not appropriate. Under those conditions, a consistent, "emotion-free" response is desired. Error-correction strategies will be more effective if students are taught first what acceptable and unacceptable behaviors look like, and what consequences are likely to follow each. Error correction strategies should be applied in a "businesslike" manner. Other than signaling the student that he or she has made an error the teacher should minimize attention for the problem behavior and emphasize attention to more appropriate replacement behaviors.

The following are general error correction steps for both academic and social behavior errors (Colvin, Sugai, \& Patching, 1993):

a. Secure the student's attention and signal that he or she has made an error.

b. Look for error patterns or misrules that the student might have learned.

c. Re-teach prerequisite skills or functional alternative behaviors.

d. Provide opportunities for the student to practice the correct response.

e. Test the student for the correct response.

f. Provide positive reinforcement when the student displays the appropriate behavior.

If the error continues to occur (chronic error), a more comprehensive and specialized intervention may be required.

\section{Teach and plan for smooth transitions}

Shifting from one activity to another consumes much instructional time and can be particularly difficult for students, especially those who display challenging behavior. Similar to all other social skills, teachers should not assume that students will know what behaviors are expected of them during transitions. Examples of appropriate transition behavior should be related to the general schoolwide rule. Transitions should be viewed as one more skill to teach, practice, and reinforce. Successful transitions are associated with (a) teaching clear expectations for student behavior; (b) establishing clear expectations for staff behavior during transitions; (c) preplanning transition implementation; (d) following transition routines consistently; and (e) providing regular and frequent acknowledgements for successful transitions.

\section{INDIVIDUAL MANAGEMENT PROCEDURES}

Preliminary research indicates that approximately 3\%$7 \%$ of students account for more than half of all office referrals in many schools (see Sugai \& Horner, 1994; Taylor et al., 1997). The fourth level of the EBS approach focuses on the practices and procedures for educating this relatively small proportion of students whose individual behaviors have a disproportionately high impact on the functioning of schoolwide, nonclassroom, and classroom systems.

\section{Preparing for Implementation}

Effective and efficient programming for individual students who present high rates of challenging behavior is directly affected by several factors.

1. The success of any individual behavior change plan is directly related to the effectiveness of the larger schoolwide system (Mayer, 1995; Sugai \& Horner, 1994, Taylor-Greene et al., 1997).

2. Any student who displays chronic challenging behavior requires a team-based approach in which all school staff work collaboratively. Because these students presented significant challenges, the efforts of a single staff member (e.g., administrator, counselor, special educator) are unlikely to be effective in meeting the complex and intense needs of these student.

3. Every adult, including support staff members who interact with the student, should be aware of all instructional plans.

4. The initial assessment and planning steps will require a large investment of time at first.

5. Data must be collected to monitor the program's effectiveness and the integrity of interventions. 


\section{Implementation Activities}

Establishing a system for meeting the needs of students with severe problem behavior occurs within the context of the larger schoolwide system. The school EBS team must make the process of setting up this system a high priority. In general, the following steps characterize the individual student system.

\section{Identify students who are in need of individualized behavior support}

Rather than waiting until a student has accumulated many office referrals or is involved in a significant episode of problem behavior, a procedure should be developed to identify students before their problem behavior becomes chronic. In many schools, teacher assistance teams serve this function. Teachers who have a student with behavior difficulties can present their situation to a team of colleagues who provide suggestions for intervention.

Another strategy for early identification is to systematically screen for high-risk students. For example, teachers could use the Systematic Screening for Behavior Disorders, developed by Hill Walker and his colleagues, to review their class lists and to screen for students who could benefit from more intensive interventions. A series of three "gates" or screens is used to identify these students.

A final example of early screening involves tracking behavioral incidents and "flagging" students who exceed a specified number of incidents. For example, one school uses a "three incidents and meet" rule. When a student receives his or her third office discipline referral for the same offense, the principal calls for an immediate teacher assistance meeting to review the student's performance and write a behavior support plan. In all of these examples, the goal is to catch students with high-risk behaviors early and thereby avoid the development of more chronic and severe problem behavior.

\section{Establish an easy means for teachers to request assistance}

Teachers must have an easy and productive way to request assistance. The request has to be simple to complete, and response to the request must occur as quickly as possible (e.g., within 48 hours).

A typical strategy that schools develop to respond to requests for assistance is to form a team of school personnel who know the student or have behavioral expertise (e.g., teacher assistance team). Teams are encouraged to provide the referring teacher with specific strategies that he or she can implement the next day. Other school staff members also should be involved in implementing the plan.

This team-based effort is necessary because the problem has been shown to be more than one person can handle and the referring teacher needs support and assistance to implement specialized interventions. For example, other staff members may be designated to (a) work with the child in settings outside of the classroom, (b) assist with developing or adapting instructional materials, or monitoring or having regular contacts with the teacher and providing additional assistance if needed.

\section{Conduct a functional behavioral assessment}

If general or typical interventions are ineffective or are determined to be insufficient, arrangements should be made for more detailed assessment of the child. A functional behavioral assessment is conducted to ascertain (a) the problem behavior, (b) conditions under which the problem behavior is and is not observed, (c) the "function" the problem behavior serves the child (what seems to be maintaining the occurrence of the behavior), and (d) direct observation data to confirm the function (Lalli, Browder, Mace, \& Brown, 1993; Lewis \& Sugai, 1996a, 1996b).

When functional behavioral assessments are conducted, an attempt is made to ascertain or hypothesize why a child engages in problem behavior. In general, children engage in problem behavior for one of two reasons: (a) to get something (e.g., adult or peer attention, access to a tangible object), or (b) to avoid something (e.g., difficult tasks, adult or peer attention).

\section{Develop a behavioral support plan based on information from functional behavioral assessments}

Once a hypothesis is formulated regarding the possible function of the problem behavior, interventions can be developed to provide students with a "prosocial" or appropriate behavior that will meet the child's needs (i.e., serve the same function as the problem behavior). Functional behavioral assessment-based interventions have two key steps. First, a "desired" replacement behavior (long-term behavioral objective) should be identified and taught to the student. In some cases, the outcomes or functions of this specific replacement behavior might be different from or incompatible with the problem behavior. For example, for a student who throws books during math to be removed (avoid) from class, raising the hand and asking for help or "trying" the work independently would be difficult to establish because these replacement behaviors have different functions.

In this situation, the identification and use of acceptable alternative replacement behaviors are required. The replacement behavior should result in outcomes for the student that are the same or similar to the outcomes associated with the problem behavior. For example, for the child who throws books during math acceptable alternatives to removing the student (avoid) from class would be behaviors that are 
socially appropriate and still allow the student to avoid doing math (e.g., giving choice of activities to complete, providing easier work, breaking tasks into smaller assignments, working with a peer tutor). These alternatives allow the student to avoid doing the difficult work independently, but they represent more acceptable ways to communicate. In this case, the instructional goal is to work toward establishing "hand raising and asking," but teaching the acceptable alternatives may be necessary as intermediary steps (shortterm objectives).

In addition to identifying and teaching replacement behaviors, a behavior support plan should specify how the school environment will be modified to (a) increase use of the targeted prosocial replacement responses, and (b) decrease the effectiveness and relevance of the problem behavior. Thus, the environment should be structured so problem behavior does not meet the child's needs (is no longer useful to the student). In the previous example, if the student throws a book, he or she would not be allowed to avoid math class. The student would still receive a consequence for throwing the book; however, the student would not be allowed to avoid the work. Rather, the instructional environment should be arranged to encourage and reinforce the use of prosocial replacement responses.

\section{Implement and monitor the behavior support plan}

To maximize the impact of the behavior support plan, implementation of its components must be accurate and consistent. Clear and practical implementation scripts or guides, regular practice or staff development opportunities, and team-based implementation can improve the accuracy and sustained use of the plan. High-intensity problem behaviors require high-intensity interventions, and initial efforts might not produce immediate effects. Early investments, however, can have significant long-term benefits.

When behavior support plans are implemented, a strategy for monitoring the impact of the plan likewise must be implemented. This monitoring strategy should involve collecting and analyzing regular, direct measures of the intervention on the behaviors of concern. Data decision rules should be established to occasion or prompt actions that would discontinue or modify ineffective interventions or adjust or sustain effective strategies. In the previous example, the data decision rule was stated as, "If the student continues to throw books for 3 consecutive schools days, call a meeting of the behavior support team." This 3 -day rule prevents situations in which the use of ineffective programs is excessive.

Figure 4 provides an example of an individual student Positive Behavioral Support Plan. The plan was generated following the above outlined steps and provides one illustration of how the recommended procedures resulted in a comprehensive plan.

\section{CONCLUSION}

Although most students experience some level of academic and social success in school, many students do not. Students who display antisocial behavior have difficulty achieving success unless schools, families, and communities organize proactive, specialized, and individualized behavioral structures and supports. This article describes essential features of a schoolwide proactive management system, Effective Behavioral Support. EBS provides a systems approach for addressing the full continuum of behavioral challenges found in schools. Many other EBS applications exist because of each school's unique features, challenges, and priorities. Nevertheless, each application shares features and themes in common.

The EBS approach focuses on enhancing schools' capacity to adopt and sustain effective practices for all students through (a) team-based problem solving and planning, (b) administrator and staff commitment and support, (c) systematic assessment of disciplinary practices and processes, (d) careful action planning, (e) ongoing staff development, and (f) data-based decision making. Four interacting and dependent school systems-schoolwide, classroom, nonclassroom, and individual student-are considered.

Four themes are emphasized throughout the EBS approach. First, the intensity of the intervention must match the intensity of the problem behavior and context in which it is observed. Universal schoolwide interventions have little impact on the behaviors of students with EBD or students who display chronic challenging behavior whose behavioral histories are more intractable and require more specialized and individualized behavioral supports.

Second, effective and efficient universal schoolwide and classroomwide systems are essential for the successful implementation of specialized group and individual student programming. A teacher cannot adequately implement a plan for two students with EBD if the classroom management system is ineffective and inefficient for the other 30 students in the classroom. Similarly, a school's ability to implement a specialized group program for the $3 \%-7 \%$ of students with high-risk behaviors is directly related to its capacity to provide a meaningful and proactive schoolwide discipline program for the remaining student body.

Third, school data are important for guiding intervention and planning decisions. Fortunately, many forms of data (e.g., office discipline referrals, attendance/tardy records, incident reports) are naturally available, but schools must establish structures, routines, and policies that increase the use and importance of data use.

Fourth, research-validated practices exist for providing behavior support at the schoolwide, classroom, nonclassroom, and individual student practices. The extent to which 


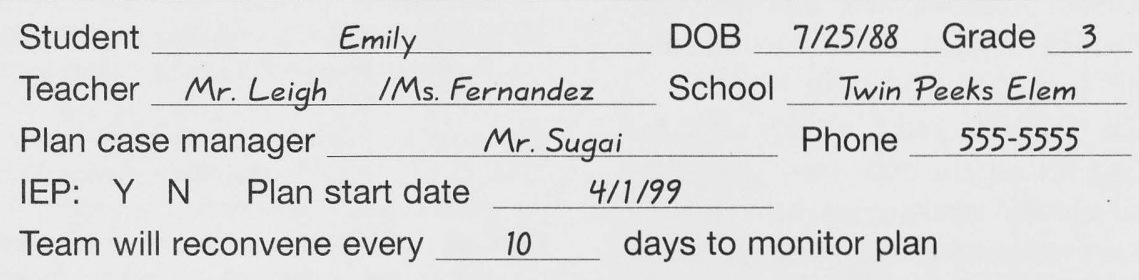

Briefly describe the problem behavior(s)

Disrupts instruction during reading and math-blurts out answers, makes loud noises, makes jokes. Occurs 10-15 times per half hour class period.

Interrupts peer activities during centers and free time-grabs materials, calls peers names. physically places self at table. Occurs $80 \%$ of the time.

Briefly describe the function the problem behavior(s) serve the student (Testable Explanation)

During academic periods, Emily interrupts instruction to access teacher and peer attention.

During peer lead activities, Emily interrupts to access peer attention.

Briefly describe a desired replacement behavior(s) that will serve a similar function as the current problem behavior

Emily will raise her hand before speaking.

Emily will remain on-task $90 \%$ of the period.

Emily will talk only about task related topics.

Emily will ask peer permission prior to joining activities.

Emily will make neutral or positive comments toward peers.

Develop a behavioral objective incorporating the replacement behavior(s)

During academic periods. Emily will remain on-task $90 \%$ of intervals for 5 consecutive days.

During independent activities. Emily will make neutral or positive comments toward peers $80 \%$ of the opportunities for 5 consecutive days.

List/describe a data collection system to monitor replacement behavior and desired criteria

Academic periods-momentary time sampling. 1 minute intervals. On-task = listening to the teacher, comments relative to task, raise hand before speaking, working on assignments in $90 \%$ of the intervals.

Independent activities - event recording, record positive/neutral comments and negative comments. Positive/neutral comments in $80 \%$ of opportunities. Opportunities $=$ neutral/positive + negative comments.

Team Members and their responsibilities for implementation Member

Mr. Leigh

Ms. Fernandez

Ms. McCathren

Ms. Garrison
Outline the instructional strategies to teach the desired replacement behavior

Emily will receive social skill instruction outlining key "on-task" behaviors. Emily will also be taught to "self-manage" her on-task behavior

Emily will receive social skill instruction focusing on appropriate peer initiations and interactions. Peer tutors will be recruited to assist in instruction.

Briefly describe the antecedent strategies that will accompany the above instructional strategies (e.g., pre-corrects, prompts, academic accommodations, schedule changes)

Pre-corrects will be used to prompt Emily on key social skills prior to academic and independent periods. Emily will be prompted to use her selfmanagement sheet prior to academic periods.

Peers will be prompted to follow class rules including ignoring students who do not comply with the rules.

Emily will receive a pre-correct prior to independent periods. Peer tutors will be prompted to assist Emily.

Outline the consequent strategies for the problem/ replacement behavior (e.g. differential reinforcement, verbal praise, error correction statements)

During academic periods, the teacher will praise Emily approximately every 3-4 minutes if she is on-task. If Emily meets daily criteria on her selfmanagement card. she can earn free-time minutes and select a peer to play with. If Emily is off-task, the teacher will provide specific verbal praise to a nearby compliant peer. If Emily continues to remain offtask, the teacher will use a simple redirective statement.

Peers who participated in the social skills training will provide verbal support to Emily if she successfully demonstrates the use of key social skills. If Emily meets her daily criteria, she can earn computer time and select a peer to work with. If Emily does not comply with the rules of the activity, the teacher will provide brief redirective statements.

Briefly describe what strategies will be used to promote generalized responding

The above strategies will be incorporated during all academic periods, including mainstream classes. "Peer tutors" will be used during other independent times (e.g. recess, cafeteria) once Emily meets criteria in the classroom.

\section{Responsibilities}

Instruction \& Data Collection

Monitor self management in classroom

Monitor program during lunch and recess

Develop social skill lessons \& self management plan

FIGURE 4

Sample individual student positive behavioral support plan. 
these practices can be identified, adopted, adapted, and, more important, sustained is related directly to whether school systems exist and work to support them.

Improving schoolwide discipline and providing effective educational programming for all students - and especially students with EBD and chronic challenging behavior-is possible; however, a more systemic and strategic approach is required. The effective behavior support approach offers opportunities for schools, parents, and communities to work smarter and systemically rather than individually to achieve these results.

\section{REFERENCES}

Alberto, P. A., \& Troutman, A. C. (1995). Applied behavior analysis for teachers (4th ed.). Englewood Cliffs, NJ: Merrill/Prentice-Hall.

American Psychological Association. (1993). Violence and youth: Psychology's response. Washington, DC: Author.

Biglan, A. (1993). A functional contextualist framework for community interventions. In S. C. Hayes, L. J. Hayes, H. W. Reese, \& T. R. Sarbin (Eds.), Varieties of scientific contextualism (pp. 251-276). Reno, NV: Context Press.

Biglan, A. (1995). Translating what we know about the context of antisocial behavior into a lower prevalence of such behavior. Journal of Applied Behavior Analysis, 28, 479-492.

Charles, C. M. (1996). Building classroom discipline: From models to practice (4th ed.). New York: Longman Inc.

Colvin, G. , Kameenui, E., \& Sugai, G. (1993). Reconceptualizing behavior management and school-wide discipline in general education. Education \& Treatment of Children, 16, 361-381.

Colvin, G., \& Lazar, M. (1997). The effective elementary classroom: Managing for success. Longmont, CO: Sopris West.

Colvin, G., Sugai, G., Good, R. H., III, \& Lee, Y. (1997). Using active supervision and precorrection to improve transition behaviors in an elementary school. School Psychology Quarterly, 12, 344-363.

Colvin, G., Sugai, G., \& Patching, B. (1993). Precorrection: An instructional approach for managing predictable problem behaviors. Intervention in School and Clinic, 28, 143-150.

Cotton, K. (1995). Effective schooling practices: A research synthesis. Portland, OR: Northwest Regional Educational Laboratory.

Cotton, K., \& Wikelund, K. R. (1990). Schoolwide and classroom discipline. School Improvement Series (Close-Up \#9). Portland OR: Northwest Regional Educational Laboratory.

Conduct Problems Prevention Research Group. (1992). A developmental and clinical model for the prevention of conduct disorders: The FAST Track Program. Development \& Psychopathology, 4, 509-527.

Dishion, T., \& Andrews, D. (1995). Preventing escalation in problem behaviors with high-risk, young adolescents: Immediate and one-year outcomes. Journal of Consulting and Clinical Psychology, 63(4), $1-11$.

Dishion, T., Patterson, G. Stoolmiller, M., \& Skinner, M. L. (1991). Family, school and behavioral antecedents to early adolescent involvement with antisocial peers. Developmental Psychology, 27, 172-180.

Dodge, K. A., \& the Conduct Problems Prevention Research Group (1993, March). Effects of intervention on children at high risk for conduct problems. Paper presented at Society for Research in Child Development, New Orleans.

Dunlap, G., Kern, L., dePerczel, M., Clarke, S., Wilson, D., Childs, K. E., White, R., \& Falk, G. D. (1993). Functional analysis of classroom variables for students with emotional and behavioral disorders. Behavioral
Disorders, 18, 275-291.

Elam, S. J., Rose, L. C., \& Gallup, A. M. (1998). 28th annual Phi Delta Kappa/Gallup poll of the public's attitudes toward the public schools. Kappan, 80(1), 41-59.

Elements of an effective discipline strategy. American Educator, 19(4), 24-27.

Elliot, D. S. (1994a). Youth violence: An overview. Boulder, CO: Center for the Study and Prevention of Violence.

Elliot, D. S. (1994b). Serious violent offenders: Onset, developmental course, and termination-American Society of Criminology 1993 Presidential Address. Criminology, 32, 1-21.

Gottfredson, G. D., \& Gottfredson, D. C. (1996). A national study of delinquency prevention in schools: Rationale for a study to describe the extensiveness and implementation of programs to prevent adolescent problem behavior in schools. Ellicott City, MD: Gottfredson Associates.

Gresham, F. M. (1998). Social skills training: Should we raze, remodel, or rebuild? Behavioral Disorders, 24, 19-25.

Guskey, T. R. (1986). Staff development and the process of teacher change. Educational Researcher, 15(5), 5-12.

Kameenui, E. J., \& Darch, C. B. (1995). Instructional classroom management: A proactive approach to behavior management. White Plains, NY: Longman.

Kameenui, E. J., \& Simmons, D. C. (1990). Designing classroom management strategies within the context of instruction. In Designing instructional strategies: The prevention of academic learning problems. Englewood Cliffs, NJ: Macmillan.

Kerr, M. M., \& Nelson, C. M. (1998). Strategies for managing problem behaviors in the classroom ( $2 \mathrm{~d}$ ed.) Columbus, $\mathrm{OH}$ : Merrill.

Koop, C. E., \& Lundberg, G. (1992). Violence in America: A public health emergency: Time to bite the bullet back. Journal of American Medical Association, 267, 3075-3076.

Lalli, J. S., Browder, D. M., Mace, F. C., \& Brown, D. K. (1993). Teacher use of descriptive analysis data to implement interventions to decrease students' problem behavior. Journal of Applied Behavior Analysis, 26, 227-238.

Larson, J. (1994). Violence prevention in the schools: A review of selected programs and procedures. School Psychology Review, 23, 151-164.

Leitman, R., \& Binns, K. (1993). The American teacher 1993: Violence in America's schools (Survey conducted for Metropolitan Life Insurance). New York: Louis Harris and Associates.

Lewis, T. J. (1996). Decision making about effective behavioral support: A guide for educators. Eugene, OR: National Center to Improve the Tools of Educators.

Lewis, T. J., Chard, D., \& Scott, T. (1994). Full inclusion and the education of children and youth with emotional and behavioral disorders. Behavioral Disorders, 19, 277-293.

Lewis, T. J., Colvin, G., \& Sugai, G. (in press). The effects of precorrection and active supervision on the recess behavior of elementary school students. Education \& Treatment of Children.

Lewis, T. J., \& Sugai, G. (1996a). Functional assessment of problem behavior: A pilot investigation of the comparative and interactive effects of teacher and peer social attention on students in general education settings. School Psychology Quarterly, 11, 1-19.

Lewis, T. J., \& Sugai, G. (1996b). Descriptive and experimental analysis of teacher and peer attention and the use of assessment based intervention to improve the pro-social behavior of a student in a general education setting. Journal of Behavioral Education, 6, 7-24.

Lewis, T. J, Sugai, G., \& Colvin, G. (1998). Reducing problem behavior through a schoolwide system of effective behavioral support: Investigation of a school-wide social skills training program and contextual interventions. School Psychology Review, 27, 446-459.

Lewis-Palmer, T., Sugai, G., \& Larson, S. (in press). Using data to guide decision about program implementation and effectiveness: Overview 
and applied example. Effective School Practices.

Lipsey, M. W. (1991). The effect of treatment on juvenile delinquents: Results from meta-analysis. In F. Losel, D. Bender, \& T. Bliesener (Eds.), Psychology and law. New York: Walter de Gruyter.

Lipsey, M. W. (1992). Juvenile delinquency treatment: A meta-analytic inquiry into the variability of effects. In T. D. Cook, H. Cooper, D. S. Cordray, H. Hartman, L. V. Hedges, R. V. Light, T. A. Louis, \& F. Mostellar (Eds.), Meta-analysis for explanation. Beverly Hills, CA: Sage.

Lipsey, M. W., \& Wilson, D. B. (1993). The efficacy of psychological, educational, and behavioral treatment: Confirmation from meta-analysis. American Psychologist, 48, 1181-1209.

Mayer, G. R. (1995). Preventing antisocial behavior in the schools. Journal of Applied Behavior Analysis, 28, 467-478.

Mayer, G. R., \& Butterworth, T. (1979). A preventive approach to school violence and vandalism: An experimental study. Personnel \& Guidance Journal, 57, 436-441.

Mayer, G. R., \& Butterworth, T. (1981). Evaluating a preventive approach to reducing school vandalism. Phi Delta Kappan, 62, 498-499.

Mayer, G. R., Nafpaktitis, M., Butterworth, T., \& Hollingsworth, P. (1987). A search for the elusive setting events of school vandalism: A correlational study. Education \& Treatment of Children, 10, 259-270.

Mayer, G. R., \& Sulzer-Azeroff, B. (1991). Interventions for vandalism. In G. Stoner, M. K. Shinn, \& H. M. Walker (Eds.), Interventions for achievement and behavior problems (pp. 559-580). Washington, DC: National Association of School Psychologists. (Monograph)

Nelson, R., \& Colvin, G. (1995). School-wide discipline: Procedures for managing common areas. In A. Deffenbaugh, G. Sugai, and G. Tindal (Eds.) The Oregon conference monograph (pp. 109-119). Eugene: University of Oregon College of Education.

Noguera, P. A. (1995). Preventing and producing violence: A critical analysis of responses to school violence. Harvard Educational Review, 65, 189-211.

O'Neill, R. E., Horner, R. H., Albin, R. W., Storey, K., \& Sprague, J. R. (1996). Functional analysis of problem behavior: A practical assessment guide (2nd Ed.). Sycamore: Sycamore IL.

Patterson, G. R., Reid, J. B., \& Dishion, T. J. (1992). Antisocial boys. Eugene, OR: Castalia Press.

Peacock Hill Working Group. (1991). Problems and promises in special education and related services for children and youth with emotional or behavioral disorders. Behavioral Disorders, 16, 299-313.

Reichle, J. (1990). National working conference on positive approaches to the management of excess behavior: Final report and recommendations. Minneapolis: Institute on Community Integration, University of Minnesota.

Rose, L. C., \& Gallup, A. M. (1998). The 30th annual Phi Delta Kappa/Gallup poll of the public's attitudes toward the public schools. Kappan, 79, 41-56.

Rutherford, R. B., \& Nelson, C. M. (1995). Management of aggressive and violent behavior in the schools. Focus on Exceptional Children, 27(6), $1-15$.

Skiba, R. J., Peterson, R. L., \& Williams, T. (1997). Office referrals and suspensions: Disciplinary intervention in middle schools. Education \& Treatment of Children, 20, 295-315.

Stokes, T. F., \& Baer, D. M. (1977). An implicit technology of generalization. Journal of Applied Behavior Analysis, 10, 349-367.

Sugai, G. (1998). Postmodernism and emotional and behavioral disorders:
Distraction or advancement. Behavior Disorders, 23, 171-177.

Sugai, G., \& Horner, R. (1994). Including students with severe behavior problems in general education settings: Assumptions, challenges, and solutions. In J. Marr, G. Sugai, \& G. Tindal (Eds.). The Oregon conference monograph (Vol. 6, pp. 102-120). Eugene, OR: University of Oregon.

Sugai, G., \& Horner, R. (in press). Discipline and behavioral support: Preferred processes and practices. Effective School Practices.

Sugai, G., \& Lewis, T. (1996). Preferred and promising practices for social skill instruction. Focus on Exceptional Children, 29(4), 1-16.

Sugai, G. M., \& Tindal, G. (1993). Effective school consultation: An interactive approach. Pacific Grove, CA: Brooks/Cole.

Taylor-Greene, S., Brown, D., Nelson, L., Longton, J. Gassman, T., Cohen, J., Swartz, J., Horner, R. H., Sugai, G., \& Hall, S. (1997). School-wide behavioral support: Starting the year off right. Journal of Behavioral Education, 7, 99-112.

Tobin, T., \& Sugai, G. (in press-a). Predicting violence at school, chronic discipline problems, and high school outcomes from sixth graders' school records. Journal of Emotional \& Behavioral Disorders.

Tobin, T., \& Sugai, G. (in press-b). Discipline problems, placements, and outcomes for students with serious emotional disturbance. Behavioral Disorders.

Tobin, T., Sugai, G., \& Colvin, G. (1996). Patterns in middle school discipline records. Journal of Emotional \& Behavioral Disorders, 4(2), 82-94.

Tolan, P., \& Guerra, N. (1994). What works in reducing adolescent violence: An empirical review of the field. Boulder, CO: Center for the Study and Prevention of Violence.

U.S. Department of Education (1995). The condition of education, 1995. Washington, DC: National Center for Education Statistics.

Wagner, M. (1991). Dropouts with disabilities: What do we know? What can we do? Menlo Park, CA: SRI International.

Walker, H. M., \& Bullis, M. (1990). Behavior disorders and the social context of regular class integration: A conceptual dilemma? In J. W. Lloyd, A. C. Repp, \& N. N. Singh (Eds.), The regular education initiative: Alternative perspectives on concepts, issues, and models (pp. 75-93). Sycamore, IL: Sycamore.

Walker, H. M., Colvin, G., \& Ramsey, E. (1995). Antisocial behavior in school: Strategies and best practices. Pacific Grove, CA: Brooks/Cole.

Walker, H. M., Horner, R. H., Sugai, G., Bullis, M., Sprague, J. R., Bricker, D., \& Kaufman, M. J. (1996). Integrated approaches to preventing antisocial behavior patterns among school-age children and youth. Journal of Emotional \& Behavioral Disorders, 4, 193-256.

Walker, H. M., \& Severson, H. H. (1990). Systematic screening for behavior disorders (SSBD). Longmont, CO: Sopris West.

Webster-Stratton, C., \& Spitzer, A. (1996). Parenting a young child with conduct problems. In Ollendick, T. H. \& Prinz, R. J. (Eds.), Advances in clinical child psychology (Vol. 18). (New York: Plenum Press), pp. $1-61$.

Wolery, M. R., Bailey, D. B. Jr., \& Sugai, G. M. (1988). Effective teaching: Principles and procedures of applied behavior analysis with exceptional children. Boston: Allyn \& Bacon.

Ziglar, E., Taussig, C., \& Black, K. (1992). Early childhood intervention: A promising preventative for juvenile delinquency. American Psychologist, 47, 997-1006. 


\section{APPENDIX A}

\section{ASSESSING AND PLANNING BEHAVIOR SUPPORT IN SCHOOLS1}

Name of school Date

Type: $\square$ Elementary $\square$ Middle/junior $\square$ High $\square$ Alternative $\square$ Other

Location: $\square$ Rural $\square$ Small urban $(<250,000) \quad \square$ Large urban $(>250,000)$

Name (optional) of person completing this survey

Position: $\square$ Administrator $\square$ General educator $\quad \square$ Special educator $\square$ Parent/family member

$\square$ Educational/teacher assistant $\quad \square$ Counselor $\square$ School psychologist $\square$ Community member

Student $\square$ Other

Total school enrollment

Estimate of number of students with chronic problem behaviors

in school enrollment (i.e., students who require extensive individualized support)

This survey was developed for use by school staff to assess and plan behavior support in their school. The information from this survey can be used to assess what is in place, what works, and what has to be modified. Survey outcomes can be used to develop a schoolwide behavior support action plan.

The survey examines the status and need to improve four behavior support "systems": (a) schoolwide discipline systems, (b) nonclassroom management systems (e.g., cafeteria, hallway, playground), (c) classroom management systems, and (d) systems for individual student with chronic problem behaviors.

To assess behavior support, first evaluate the status of each system feature (i.e. in place, partially in place, not in place) (lefthand side of survey). Next, examine each feature that is rated as partially in place or not in place and rate the degree to which improvements are needed (i.e., high, medium, low) (righthand side of survey).

To develop an action plan, summarize the responses from all completed surveys, and complete the action plan sheet. 


\section{SCHOOLWIDE SYSTEMS}

\begin{tabular}{|c|c|c|c|c|c|c|}
\hline \multicolumn{3}{|c|}{ Current Status } & \multirow{2}{*}{$\begin{array}{l}\text { Feature } \\
\text { Schoolwide is defined as involving all } \\
\text { students, all staff, \& all settings. }\end{array}$} & \multicolumn{3}{|c|}{ Improvement Priority } \\
\hline $\begin{array}{l}\text { In } \\
\text { Place }\end{array}$ & $\begin{array}{l}\text { Partial } \\
\text { in Place }\end{array}$ & $\begin{array}{l}\text { Not in } \\
\text { Place }\end{array}$ & & High & Med & Low \\
\hline & & & $\begin{array}{l}\text { 1. A small number (e.g. } 3-5 \text { ) of positively } \& \\
\text { clearly stated student expectations or rules } \\
\text { are defined. }\end{array}$ & & & \\
\hline & & & $\begin{array}{l}\text { 2. Expected student behaviors are taught } \\
\text { directly. }\end{array}$ & & & \\
\hline & & & $\begin{array}{l}\text { 3. Expected student behaviors are rewarded } \\
\text { regularly. }\end{array}$ & & & \\
\hline & & & $\begin{array}{l}\text { 4. Problem behaviors (failure to meet } \\
\text { expected student behaviors) are defined } \\
\text { clearly. }\end{array}$ & & & \\
\hline & & & $\begin{array}{l}\text { 5. Consequences for problem behaviors are } \\
\text { defined clearly. }\end{array}$ & & & \\
\hline & & & $\begin{array}{l}\text { 6. Distinctions between office and classroom- } \\
\text { managed problem behaviors are clear. }\end{array}$ & & & \\
\hline & & & $\begin{array}{l}\text { 7. Options exist to allow classroom instruc- } \\
\text { tion to continue when problem behavior } \\
\text { occurs. }\end{array}$ & & & \\
\hline & & & $\begin{array}{l}\text { 8. Procedures are in place to address emer- } \\
\text { gency/dangerous situations. }\end{array}$ & & & \\
\hline & & & $\begin{array}{l}\text { 9. A team exists for behavior support plan- } \\
\text { ning \& problem solving. }\end{array}$ & & & \\
\hline & & & $\begin{array}{l}\text { 10. School administrator is an active partici- } \\
\text { pant on the behavior support team. }\end{array}$ & & & \\
\hline & & & $\begin{array}{l}\text { 11. Staff members receive regular (monthly/ } \\
\text { quarterly) feedback on behavior patterns. }\end{array}$ & & & \\
\hline & & & $\begin{array}{l}\text { 12. School includes formal strategies for } \\
\text { informing families about expected student } \\
\text { behaviors at school. }\end{array}$ & & & \\
\hline & & & $\begin{array}{l}\text { 13. Booster training activities for students } \\
\text { are developed, modified, \& conducted based } \\
\text { on school data. }\end{array}$ & & & \\
\hline & & & $\begin{array}{l}\text { 14. Schoolwide behavior support team has a } \\
\text { budget for (a) teaching students, (b) ongoing } \\
\text { rewards, and (c) annual staff planning. }\end{array}$ & & & \\
\hline & & & $\begin{array}{l}\text { 15. All staff members are involved directly or } \\
\text { indirectly in schoolwide interventions. }\end{array}$ & & & \\
\hline
\end{tabular}




\section{NONCLASSROOM SETTING SYSTEMS}

\begin{tabular}{|c|c|c|c|c|c|c|}
\hline \multicolumn{3}{|c|}{ Current Status } & \multirow{2}{*}{$\begin{array}{l}\text { Feature } \\
\text { Nonclassroom settings are defined as } \\
\text { particular times or places where supervision } \\
\text { is emphasized (e.g., hallways, cafeteria, } \\
\text { playground, bus). }\end{array}$} & \multicolumn{3}{|c|}{ Improvement Priority } \\
\hline $\begin{array}{c}\text { In } \\
\text { Place }\end{array}$ & $\begin{array}{l}\text { Partial } \\
\text { in Place }\end{array}$ & $\begin{array}{l}\text { Not in } \\
\text { Place }\end{array}$ & & High & Med & Low \\
\hline & & & $\begin{array}{l}\text { 1. Schoolwide expected student behaviors } \\
\text { apply to nonclassroom settings. }\end{array}$ & & & \\
\hline & & & $\begin{array}{l}\text { 2. Schoolwide expected student behaviors } \\
\text { are taught in nonclassroom settings. }\end{array}$ & & & \\
\hline & & & $\begin{array}{l}\text { 3. Supervisors actively supervise (move, } \\
\text { scan, \& interact with) students in nonclass- } \\
\text { room settings. }\end{array}$ & & & \\
\hline & & & $\begin{array}{l}\text { 4. Rewards exist for meeting expected stu- } \\
\text { dent behaviors in nonclassroom settings. }\end{array}$ & & & \\
\hline & & & $\begin{array}{l}\text { 5. Physical/architectural features are modi- } \\
\text { fied to limit (a) unsupervised settings, (b) } \\
\text { unclear traffic patterns, and (c) inappropriate } \\
\text { access to \& exit from school grounds. }\end{array}$ & & & \\
\hline & & & $\begin{array}{l}\text { 6. Scheduling of student movement ensures } \\
\text { appropriate numbers of students in non- } \\
\text { classroom spaces. }\end{array}$ & & & \\
\hline & & & $\begin{array}{l}\text { 7. Staff receives regular opportunities for } \\
\text { developing and improving active supervision } \\
\text { skills. }\end{array}$ & & & \\
\hline & & & $\begin{array}{l}\text { 8. Status of student behavior and manage- } \\
\text { ment practices are evaluated quarterly from } \\
\text { data. }\end{array}$ & & & \\
\hline & & & $\begin{array}{l}\text { 9. All staff members are involved directly or } \\
\text { indirectly in management of nonclassroom } \\
\text { settings. }\end{array}$ & & & \\
\hline
\end{tabular}


CLASSROOM SYSTEMS

\begin{tabular}{|c|c|c|c|c|c|c|}
\hline \multicolumn{3}{|c|}{ Current Status } & \multirow{2}{*}{$\begin{array}{l}\text { Feature } \\
\text { Classroom settings are defined as } \\
\text { instructional settings in which teacher(s) } \\
\text { supervise \& teach groups of students. }\end{array}$} & \multicolumn{3}{|c|}{ Improvement Priority } \\
\hline $\begin{array}{l}\text { In } \\
\text { Place }\end{array}$ & $\begin{array}{l}\text { Partial } \\
\text { in Place }\end{array}$ & $\begin{array}{l}\text { Not in } \\
\text { Place }\end{array}$ & & High & Med & Low \\
\hline & & & $\begin{array}{l}\text { 1. Expected student behavior \& routines in } \\
\text { classrooms are stated positively \& defined } \\
\text { clearly. }\end{array}$ & & & \\
\hline & & & 2. Problem behaviors are defined clearly. & & & \\
\hline & & & $\begin{array}{l}\text { 3. Expected student behavior \& routines in } \\
\text { classrooms are taught directly. }\end{array}$ & & & \\
\hline & & & $\begin{array}{l}\text { 4. Expected student behaviors are acknowl- } \\
\text { edged regularly (positively reinforced) }(>4 \\
\text { positives to } 1 \text { negative). }\end{array}$ & & & \\
\hline & & & $\begin{array}{l}\text { 5. Problem behaviors receive consistent con- } \\
\text { sequences. }\end{array}$ & & & \\
\hline & & & $\begin{array}{l}\text { 6. Procedures for expected \& problem } \\
\text { behaviors are consistent with schoolwide } \\
\text { procedures. }\end{array}$ & & & \\
\hline & & & $\begin{array}{l}\text { 7. Options exist to allow classroom instruc- } \\
\text { tion to continue when problem behavior } \\
\text { occurs. }\end{array}$ & & & \\
\hline & & & $\begin{array}{l}\text { 8. Instruction \& curriculum materials are } \\
\text { matched to student ability (math, reading, } \\
\text { language). }\end{array}$ & & & \\
\hline & & & $\begin{array}{l}\text { 9. Students experience high rates of acade- } \\
\text { mic success }(\geq 75 \% \text { correct). }\end{array}$ & & & \\
\hline & & & $\begin{array}{l}\text { 10.Teachers have regular opportunities for } \\
\text { access to assistance \& recommendations } \\
\text { (observation, instruction, \& coaching). }\end{array}$ & & & \\
\hline & & & $\begin{array}{l}\text { 11. Transitions between instructional \& non- } \\
\text { instructional activities are efficient \& orderly. }\end{array}$ & & & \\
\hline
\end{tabular}




\section{INDIVIDUAL STUDENT SYSTEMS}

\begin{tabular}{|c|c|c|c|c|c|c|}
\hline \multicolumn{3}{|c|}{ Current Status } & \multirow{2}{*}{$\begin{array}{l}\text { Feature } \\
\text { Individual student systems are defined as } \\
\text { specific supports for students who engage } \\
\text { in chronic problem behaviors ( } 1 \%-7 \% \text { of } \\
\text { enrollment). }\end{array}$} & \multicolumn{3}{|c|}{ Improvement Priority } \\
\hline $\begin{array}{l}\text { In } \\
\text { Place }\end{array}$ & $\begin{array}{l}\text { Partial } \\
\text { in Place }\end{array}$ & $\begin{array}{l}\text { Not in } \\
\text { Place }\end{array}$ & & High & Med & Low \\
\hline & & & $\begin{array}{l}\text { 1. Assessments are conducted regularly to } \\
\text { identify students with chronic problem } \\
\text { behaviors. }\end{array}$ & & & \\
\hline & & & $\begin{array}{l}\text { 2. A simple process exists for teachers to } \\
\text { request assistance. }\end{array}$ & & & \\
\hline & & & $\begin{array}{l}\text { 3. A behavior support team responds } \\
\text { promptly (within } 2 \text { working days) to students } \\
\text { who present chronic problem behaviors. }\end{array}$ & & & \\
\hline & & & $\begin{array}{l}\text { 4. Behavioral support team includes an } \\
\text { individual skilled at conducting functional } \\
\text { behavioral assessment. }\end{array}$ & & & \\
\hline & & & $\begin{array}{l}\text { 5. Local resources are used to conduct } \\
\text { functional assessment-based behavior } \\
\text { support planning }(\sim 10 \mathrm{hrs} / \text { week/student). }\end{array}$ & & & \\
\hline & & & $\begin{array}{l}\text { 6. Significant family and community } \\
\text { members are involved when appropriate } \\
\& \text { possible. }\end{array}$ & & & \\
\hline & & & $\begin{array}{l}\text { 7. School includes formal opportunities for } \\
\text { families to receive training on behavioral } \\
\text { support/positive parenting strategies. }\end{array}$ & & & \\
\hline & & & $\begin{array}{l}\text { 8. Behavior is monitored \& feedback } \\
\text { provided regularly to the behavior support } \\
\text { team \& relevant staff. }\end{array}$ & & & \\
\hline
\end{tabular}


BEHAVIOR SUPPORT SURVEY SUMMARY

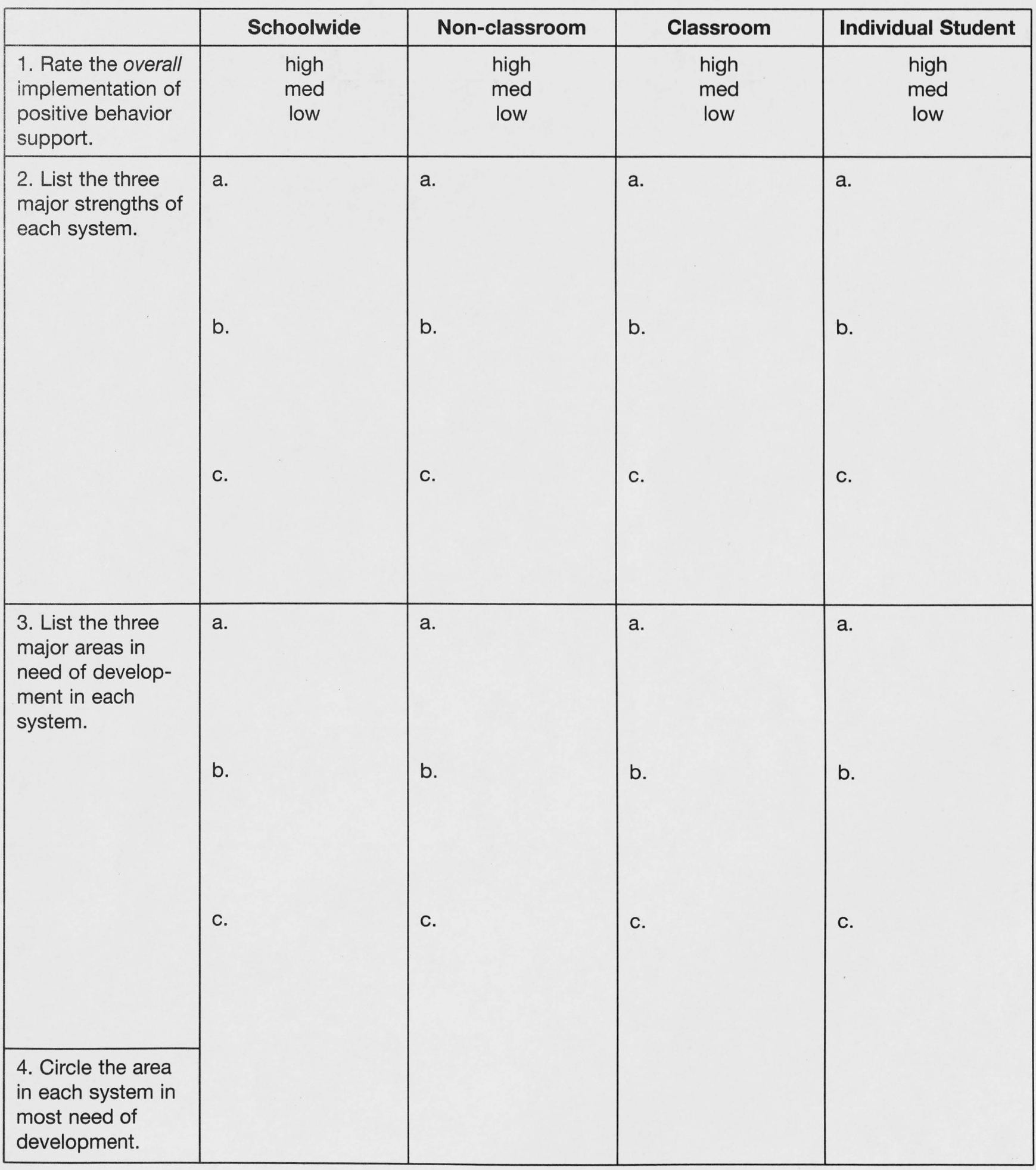




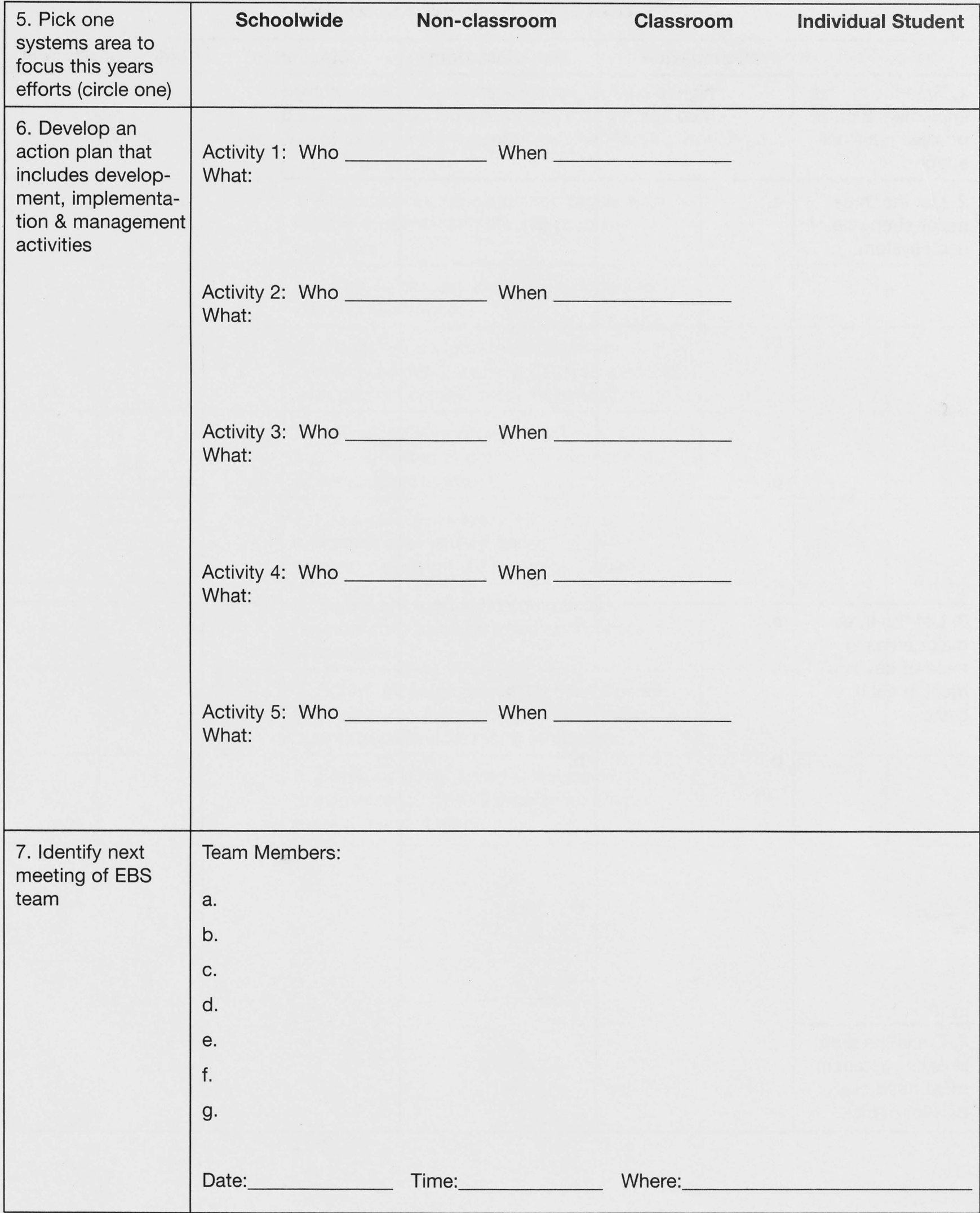

